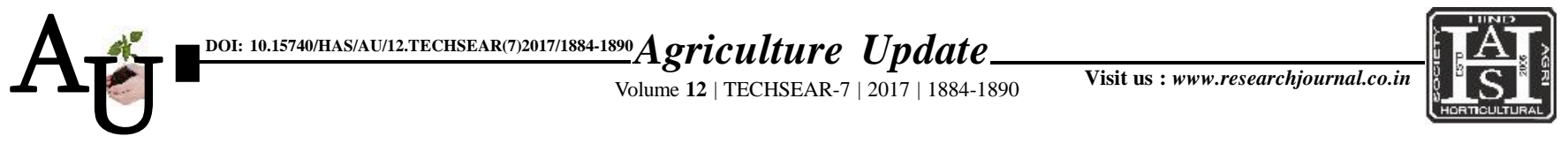

\title{
Research article: Effect of NPK application through different approaches on yield and major nutrient uptake by finger millet (Eleusine coracona L.) under rainfed conditions
}

\section{SARASWATHI, Y. VISHAWANATH SHETTY, M. DINESH KUMAR AND M. ASHWINI}

Article Chronicle:

Received :

19.07.2017;

Accepted :

03.08.2017

KEY WoRDS:

STCR, Target yields

STL, Partial factor

productivity
SUMMARY : A field experiment was conducted on alfisols during 2013 of Zonal Agricultural and Horticultural Research Station, College of Agriculture, Navile, Shivamogga. To study the effect of NPK application through different approaches on yield and major nutrient uptake by finger millet (Eleusine coracona $\mathrm{L}$.) under rainfed conditions. A total of nine treatments were tried in a Randomized Complete Block Design (RCBD) with three replications. The treatments comprise of RDF + compost $10 \mathrm{tha}^{-1}, \mathrm{RDF}$ $+50 \% \mathrm{NK}+$ compost $10 \mathrm{t} \mathrm{ha}^{-1}$, STCR based NPK + compost $10 \mathrm{t} \mathrm{ha}^{-1}$, STL based NPK + compost $10 \mathrm{t}$ ha $^{-1}$, RDF through enriched compost, RDF $+50 \%$ NK through enriched compost, STCR based through enriched compost, STL based through enriched compost, with a control. The results revealed that application of STCR based NPK and compost $10 \mathrm{t} \mathrm{ha}^{-1}$ for targeted yield $40 \mathrm{q} \mathrm{ha}^{-1}$ recorded a highest grain yield (3238.00 $\left.\mathrm{kg} \mathrm{ha}^{-1}\right)$ and straw yield $\left(8926.00 \mathrm{~kg} \mathrm{ha}^{-1}\right)$. Similarly higher uptake was recorded in STCR based NPK + compost $10 \mathrm{t} \mathrm{ha}^{-1}$ both in grain and straw. The highest partial factor productivity was recorded in $\mathrm{T}_{2}$ which receive $\mathrm{NPK}+50 \% \mathrm{NK}+$ compost $10 \mathrm{t} \mathrm{ha}^{-1}$.

How to cite this article : Saraswathi, Shetty, Y. Vishawanath, Kumar, M. Dinesh and Ashwini, M. (2017). Effect of NPK application through different approaches on yield and major nutrient uptake by finger millet (Eleusine coracona L.) under rainfed conditions. A gric. Update, 12(TECHSEAR-7) : 1884-1890; DOI: 10.15740/ HAS/AU/12.TECHSEAR(7)2017/1884-1890.
Author for correspondence :

\section{SARASWATHI}

Department of Soil

Science and Agricultural

Chemistry, University of Agricultural and Horticultural Sciences, SHIMOGA (KARNATAKA) INDIA

See end of the article for authors' affiliations 